\title{
The Role of Employees Job Satisfaction in the Relationship between Transformational Leadership and Affective Commitment at Roof-Tile Manufacturing Company
}

\author{
Tri Widarmanti (Corresponding author) \\ School of Economics and Business, Telkom University \\ Jl. Telekomunikasi No 1 Bandung, Indonesia \\ E-mail: triwidarmanti@telkomuniversity.ac.id \\ Arif Partono Prasetio \\ School of Economics and Business, Telkom University \\ Jl. Telekomunikasi No 1 Bandung, Indonesia \\ E-mail: partono@telkomuniversity.ac.id
}

\author{
Bachruddin Saleh Luturlean \\ School of Communications and Business, Telkom University \\ Jl. Telekomunikasi No 1 Bandung, Indonesia \\ E-mail: bachruddinsaleh@telkomuniversity.ac.id
}

Received: Dec. 29, 2020 Accepted: Jan. 23, $2021 \quad$ Online published: Feb. 17, 2021

doi:10.5296/ijhrs.v11i1.18124ＵRL: https://doi.org/10.5296/ijhrs.v11i1.18124

\begin{abstract}
Human resources play a strategic and important role to achieve company's vision and mission, the quality of human resources will affect the performance and progress of an organization. Commitment is very important for organization, a strong affective commitment encourages employees to contribute better, there are constructive factors of affective commitment such as transformational leadership and job satisfaction. This study wants to examine the relationship
\end{abstract}


between transformational leadership, affective commitment, and job satisfaction and the effect of transformational leadership practices on affective commitment directly and indirectly through the mediating role of job satisfaction in tile rooftop manufacturers at Jatiwangi Indonesia. A quantitative survey approach has been used, and 5 hypotheses were tested with a sample 184 of 350 employees of roof-tile manufactures was selected to answer the questionnaire. Data collected based on descriptive analytics processed by SPSS Software, and the result of this study show that there is a positive relationship between these variables, transformational leadership significant positive relations to job satisfaction and affective commitment and job satisfaction becomes a partial mediator variable in the relationship between transformational leadership with affective commitment, but yet those 4 company still not represent all roof-tile company in Indonesia, future studies could replicate the current one by collecting data from different sources.

Keywords: transformational leadership, affective commitment, job satisfaction, roof-tile company in Indonesia.

\section{Introduction}

Human resource management (HRM) practices help managers accomplish organizational goals by successfully handling jobs and people in organizations (Boxall and Purcell, 2003), HRM deals with human beings working in an organization, need a humanistic approach to manage people towards working effectively in an organization (Shah et al., 2020). Human resources play a strategic role and have a firm position in company (Rajnoha and Lesníková, 2016), their activities contribute to achieving goals of group of workers, department and corporate (Mura et al., 2017) this is the fact that Human resources has an important role in reaching the company's vision and mission, company need qualified human resources that have superior performance to compete during global competition. Quality of human resources is a resource that is needed by company (Octaviannand, 2017) and involvement human resource play an important role in employees' affective commitment (Yang, 2012).

Employee commitment is very important for organizations in today competitive business world. Good human resource management is when employees have a high commitment, especially affective commitment (Dinc and Plakalovic, 2016), affective component, continuance component and normative component are three component model of organizational commitment Allen's Study (1991, as cited in Dinc and Plakalovic, 2016). Affective commitment that arises from self-awareness will be a driving factor for employees in carrying out work optimally. Strong commitment arises when employees feel an emotional connection (Manuel and Rahyuda, 2015). The alignment of organizational goals with individual employee goals is believed to increase strong commitment (Harthantyo and Raharjo, 2017) from these studies it can be understood that the organization needs to build a strong commitment among employees, Strong affective commitment than employees will contribute better, and affective commitment can develop by managing several conditions in the company. Affective commitment needs to be developed and managed by the organization, since the benefit has been great. Although affective commitment has been thoroughly researched in many areas, the research in family companies, especially in tile-roof 
manufactures has never been carried out, and never been measured, this study used transformational leadership and job satisfaction as the main factors to strengthen the study. -

Previously, researchers examined the constructive factors of affective commitment, such as clarity of job goals and objective job appraisals (Park and Rainey, 2007), job stress (Yang et al., 2017; Ali et al., 2011 ), learning culture (Joo, 2020; Islam, 2015), compensation (Paik et al., 2007; Nawab and Batthi, 2011), employee job satisfaction and motivation level (Sohail et al., 2014; Tosun and Ulusoy, 2017), perceptions of the importance of employee roles (Sanders, 2008; McCormick and Donohue, 2016), confident and belief in one's own abilities (Giovanita, 2017), transformational leadership (Dlamini et al., 2017; Riaz et al., 2011; Shah et al., 2020), and procedural justice (Charbon-neau and Wood, 2018). The diversity of factors that build the employee affective commitment will make it easier for organizations to have a program to implement.

This study wants to examine the relationship and the effect of transformational leadership practices on affective commitment directly and indirectly through the mediating role of job satisfaction. Leaders have a big role in supporting the success of contributing to the organization. By applying a transformational leadership style, employees are expected to feel more comfortable at work, because they feel comfortable at work, they are then expected to be satisfied with the work and the organization, these two elements are expected to increase affective commitment to the organization. Transformational leadership is known as a positive leadership style in which leaders' value innate contributions, listen to input, and involve employees in decision making. This will bring out a feeling of being valued in employees. This positive support will encourage perceptions associated with job satisfaction and increase affective commitment (Malik et al., 2017; Qing et al., 2019)

This study conducted at four manufactures companies engaged in roof-tiled in Jatiwangi -West Java Indonesia. For company, achieving business goal is very important, leader need to motivate the employees and reach companies objectives, employees with optimal performance are expected to be the core of organization success. Based on interviews, managers of human resources from the company, the level of affective commitment of employees was found to be at a moderate level. It is seen from the relatively low awareness of employees to contribute more, for example when working hours are over, they feel that the day's work has been completed, employees feel their job is a burden, they are not considered the work is to develop themselves and the organization. Company expects optimal employee performance, they use a resource management approach to build their employees' affective commitment by looking on to how to raise the level of affective commitment, the management attract to the two things, it is a leadership style and job satisfaction level in the company. Based on the result of the reviews this study wants to focus to leadership style and job satisfaction, also want to measure the extent of employee satisfaction, and identify whether leadership style and job satisfaction level can be an appropriate basis for increasing affective commitment. This study expected to provide accurate answers so that the management and implementation of policies related to human resources in this organization can be carried out effectively. 


\subsection{Transformational Leadership and Job Satisfaction}

Transformational leader is a leader who motivates follower through inspiration, the leader offered challenge to the followers and support their personality development (Shurbagi, 2014), Spector's study (1985 as cited in Subhargi, 2014) views job satisfaction as an area of evaluation feeling about the job. Transformational leadership and job satisfaction are essential elements to reaching the achievement of organization, job satisfaction will lead to contribute more to organizational goals execution. A good leader positively influences employee behavior related to increased satisfaction. There was positive relationship between leadership and job satisfaction, and leadership had an effect on job satisfaction Robbin's study (1996, as cited in Sang et al., 2019), Yates (2014) stated that ethical leadership was positively correlated with job satisfaction and organizational commitment. Transformational leadership positively influences job satisfaction (Kiarie et al., 2017; Choi et al, 2016; Yang and Lim, 2016; Kiboss and Jemiryott, 2014) this is support by Boamah et al (2018) who stated that transformational leadership has a strong positive effect on the empowerment of the workplace, which in turn improved job satisfaction. Yang's study (2012, as cited in Abdullah et al., 2017) found that job satisfaction acts as a mediator between transformational leadership. These studies were conducted using diverse respondents from a variety of industries such as banks, hospitals, restaurants, education, media, hotels. This diversity of the backgrounds of the industry can reinforce the view that transformational leadership is positively associated with job satisfaction. Therefore, this study proposed the hypothesis

\section{H1: Transformational leadership has significantly and positively affected the job satisfaction}

\subsection{Transformational Leadership and Affective Commitment}

Transformational leadership and affective commitment, leadership is one final factor that affects performance significantly (Abdullah et al., 2017). Several previous studies have specifically explored the effect of transformational leadership on affective commitment, such as (Yang, 2012; Nguni et al., 2006; Abdullah et al., 2017) their studies found that transformational leadership behaviors be the primary determinant of affective commitment. Ramachandran and Krishan study (2009, as cited in Amin et al., 2018) stated that commitment of employee significantly affected by leadership style, and Van der Voet (2016) study in a public sector and the result show that transformational leadership contribute to the process of organizational change and increases the affective commitment. In line with Jung (2016) who study about transformational leadership and affective commitment at a hospital Korea, Jung stated that the ethical leadership training programs for head nurses are likely to improve affective commitment and job satisfaction among staff nurses, and Işik (2020) also found a positive relationship between ethical leadership to affective commitment and job satisfaction. In the term of fostering creativity and innovation, an affective commitment was moderating the effect of transformational leadership on creativity (Khaola, 2019), therefore, this study proposed the hypothesis

H2: Transformational leadership has significantly and positively affected the affective commitment 
H3: Transformational leadership has an indirect effect on affective commitment

\subsection{Job Satisfaction and Affective Commitment}

Job satisfaction and affective commitment are often discussed in research related to employee work behavior. Spector Study (1997 as cited in Alkhateri et al., 2018) defines job satisfaction as an attitude reflecting on how well people like or dislike their job. Job satisfaction is the degree to which people are pleased with their work and how they feel about various aspects of their job. (Agho et al., 1993; Chu et al., 2003 as cited in Alkhateri et al., 2018). Affective commitment refers to individual commitment to the organization is simply motivated by affiliation with the organization and emotional connection. (Allen and Meyer, 1996 as cited in Alkhateri et al., 2018).

Employees with affective commitment develop a closer and more emotional relationship with the organization. The emotional attachment makes employees working harder and seriously. Jung (2016) study stated that affective commitment plays a complete mediating role with an effect on the relationship between ethical leadership and job satisfaction, Abdallah (2016) stated that job involvement positively and important effect on job satisfaction and organizational commitment, (Alkhateri et al., 2018) also stated that job satisfaction predicts affective commitment substantially. In addition, different studies have reported similar findings in relation to affective involvement as an aspect of organizational commitment. This result further supports the proposition that if the organization pays attention to their degree of happiness, workers can reach a higher level of affective involvement that is required by the company. Based on those facts this study proposed the hypothesis:

H4: The job satisfaction has significantly and positively affected the Affective Commitment.

In addition, the research question related to the relationship of transformational leadership, affective commitment, and job satisfaction, Shurbagi (2014) found the effect of organizational commitment as a mediating variable on this relationship in Petroleum sector in Libya, the relationship between transformational leadership and job satisfaction affects organizational commitment. Chen's study (2004, as cited in Shurbagi (2014) confirmed organizational commitment as mediate in the relationship between transformational leadership behaviors and job satisfaction. This study determines the following hypothesis.

H5: Job satisfaction will mediate the relationship between transformational leadership and Affective Commitment

\section{Method}

Based on literature review this study used a causal descriptive quantitative research method. Descriptive is used to present findings specifically how employees perceive the behavior under study and causal is used to explain the causal model among variables. The influence between variables was measured using SPSS and explained using path analysis techniques. Path analysis is also the basis for describing direct and indirect relationships (Riduan and Kuncoro, 2012). 
Table 1. Demographic Characteristics

\begin{tabular}{cccc}
\hline Demography & Category & Respondents & $\mathbf{\%}$ \\
\hline Sex & male & 127 & $69 \%$ \\
& female & 57 & $31 \%$ \\
\hline Age & $<25$ year & 6 & $3 \%$ \\
& $>25-30$ year & 21 & $11 \%$ \\
& $>30-35$ year & 32 & $17 \%$ \\
& $>35-40$ year & 37 & $20 \%$ \\
& $>40-45$ year & 54 & $29 \%$ \\
& $>45-50$ year & 31 & $17 \%$ \\
& $>50$ year & 3 & $2 \%$ \\
\hline Education & SD & 127 & $69 \%$ \\
& SMP & 42 & $23 \%$ \\
& SMA & 13 & $7 \%$ \\
& Diploma & 1 & $1 \%$ \\
& S1 & 1 & $1 \%$ \\
\hline Tenure & $<1$ year & 11 & $6 \%$ \\
& $1-3$ year & 53 & $29 \%$ \\
& $>3-5$ year & 46 & $25 \%$ \\
& $>5-10$ year & 46 & $25 \%$ \\
& $>10$ year & 28 & $15 \%$ \\
\hline Position & Officer & 155 & $84 \%$ \\
& Supervisor & 26 & $14 \%$ \\
& Manager & 3 & $2 \%$ \\
\hline & & &
\end{tabular}

This study employed the survey method in which the questionnaires was developed from job satisfaction question-based Robbins and Judge (2017), transformational leadership based on Baysak and Yener (2015) and Affective commitment based on Meyer and Allen (1991). Each question developed using Likert scale statement. There are 350 total employees from 4 companies of roof-tile, this study distributed 240 questionnaires and received 184 useable reponds which represents the employee population in the organization. Based on gender, 127 respondents are male and 57 are female, most are primary school respondents, and the rest are above, and $79 \%$ of the employees have worked for more than $1-10$ years.

A reliability analysis using Cronbach's alpha was run on 30 items questions to measure the construct, all question items are declared valid, and alpha Cronbach's 0.8 greater than 0.7 , all variables are reliable. To test the significance of indirect effects, this study used bootstrapping process Macro (Hayes et al., 2017; Hayes, 2018). Bootstrapping considered as an effective solution to avoid the normality of sampling distribution assumptions (Preacher et. al., 2007).

\section{Results}

Table 2. shows the inter-construct correlations with means and standard deviation. The analysis of correlation between job satisfaction and transformational leadership. There exists adequate evidence to show that transformational leadership statistically significant and positively affect to job satisfaction $(\beta=0.587, \mathrm{SE}=0.071, \mathrm{p}=0.00)$ support the $\mathrm{H} 1$, transformational leadership statistically significant and positively affect to affective commitment $(\beta=0.356, \mathrm{SE}=0.072, \mathrm{p}=0.00)$ this support $\mathrm{H} 2$, and job satisfaction statistically significant and positively affect the affection commitment $(\beta=0.544, \mathrm{SE}=0.064$, $\mathrm{p}=0.00$ ) in manufacture roof-tiled company in Jatiwangi, this is support the H4 
Based on the outcome, the association between the research variables, the relationship between variables could be inferred; transformational leadership, job satisfaction, and affective commitment were significantly having a positive relation. And these results consistent with previous study by Shurbagi (2014).

Table 2. Correlation

\begin{tabular}{lccccccc} 
& \multicolumn{3}{c}{ Transformational Leardship } & \multicolumn{3}{c}{ Job Satisfaction } \\
\hline & Coeff & SE & \multicolumn{2}{c}{ p-value } & Coeff & SE & \multicolumn{1}{c}{ p-value } \\
\hline Job Satisfaction & 0.587 & 0.071 & 0.000 & - & - & - \\
Affective Commitmen1 1 & 0.356 & 0.072 & 0.000 & 0.544 & 0.064 & 0.000 \\
Constant & 1.810 & 0.323 & 0.000 & 0.226 & 0.303 & 0.457 \\
\cline { 2 - 8 } & R Square & 0.274 & & R Square & 0.516 & \\
& $\mathrm{~F}=$ & 68.8 & & $\mathrm{~F}=$ & 96.7 & \\
& $\mathrm{p}=$ & 0 & & $\mathrm{p}=$ & 0 & \\
\hline
\end{tabular}

Table 3 shows that their significance test relates to the prediction of the mediation of job satisfaction between transformational leadership and affective commitment. The result indicates that there is an indirect effect of transformational leadership on affective commitment (support H3) and estimate of this effect $(\beta=0.3197)$ as well as a bootstrapped standard error and confidence interval. 95\% confidence intervals contain the true value of a parameter in $95 \%$ of samples, b-value for the indirect effect falls between 0.1588 and 0.5146 . This range does not include zero, which means that there is likely to be a genuine indirect effect. Job satisfaction is a mediator of the relationship between transformational leadership and affective commitment, this is support H5

Table 3. Indirect Effect of Job Satisfaction in the Relationship Between Transformational Leadership and Affective Commitment

Effect of Transformational Leadership on Affective Commitment

\begin{tabular}{ccccc}
\hline & Effect & Boot SE & BootLLCI & BootULCI \\
\hline $\begin{array}{c}\text { Transformational } \\
\text { Leadership -> Job }\end{array}$ & & & & \\
Satisfaction -> Affective & 0.3197 & 0.925 & 0.1588 & 0.5146 \\
Commitment & & & & \\
\hline
\end{tabular}

\section{Discussion}

This study obtained to describe the relationship between transformational leadership, job satisfaction, and affective commitment, and the effect of transformational leadership on these variables in roof-tiled manufacture company Jatiwangi - Indonesia. This study found that there is a positive relationship between these variables, transformational leadership significant positive relations to job satisfaction and affective commitment. These results are mostly consistent with the previous studies, Rebeiro et al study at Turkey stated that transformational leadership relates to affective commitment, transformational leadership promotes employees' affective commitment (Ribeiro et al., 2018), in line with Abouraia and Othman (2017) study in the financial market of Jeddah, Saudi Arabia, they found there was a 
significant and positive connection between transformational leadership, job satisfaction, and organizational commitment. Similar to the findings in Luu and Phan (2020) study in Vietnam the result remains the same there a positive connection between transformational leadership, job satisfaction, and organizational commitment. The finding of this study and previous studies have further strengthened the empirical support that transformational leadership is the factor that influence affective commitment.

The findings of this study show that the relationship between independent variable and dependent variable is significant when mediator variable is included, therefore this study concludes that job satisfaction becomes a partial mediator variable in relationship between transformational leadership with affective commitment, support by Rahman and Rashid (2018) study, so transformational leadership not only directly influence the affective commitment but also influences affective commitment through job satisfaction, this also explains that the affective commitment of leader to implement the transformational leadership can be enhanced and driven by their job satisfaction through the stimulus of directors' transformational leadership practices. However, these findings of this study quite differ from Rahmi (2014) study result at SMA in East Lombok, Rahmi's study shows job satisfaction did not play a role as a mediator in the relationship between transformation leadership practice and affective commitment among teachers. The difference happens possibility because of contexts, theory, and scope of the study is differing.

This study has certain limitation, the research data does not represent all tile companies, Since the data used in this analysis was obtained at one point in time from four sources, the problem of common method bias cannot be ruled out, future studies may repeatedly collect the data from the same sample over an extended period of time.

Overall, this study result showed that there was a significant positive relationship between all dimensions of transformational leadership, job satisfaction and affective commitment among employees in roof-tiled manufacturing company in Jatiwangi - Indonesia. A leader who practices the dimensional of transformational leadership will increase the affective commitment, in the other hands job satisfaction serves as a mediator in the relationship of transformational leadership and affective commitment, since we know that job satisfaction plays important role toward affective commitment and transformational leadership, the manager should develop employee satisfaction to increase their affective commitment in implementing the transformational leadership.

\section{References}

Abouraia, M. K., \& Othman, S. M. (2017). Transformational leadership, job satisfaction, organizational commitment, and turnover intentions: the direct effects among bank representatives. American Journal of Industrial and Business Management, 7(4), 404-423. https://doi.org/10.4236/ajibm.2017.74029

Abdallah, A. B., Obeidat, B. Y., Aqqad, N. O., Al Janini, M. N. E. K., \& Dahiyat, S. E. (2016). An integrated model of job involvement, job satisfaction and organizational commitment: A structural analysis in Jordan's banking sector. Communications and Network, 9(1), 28-53. 
https://doi.org/10.4236/cn.2017.91002

Abdullah, A. G. K., Ling, Y. L., \& Ping, C. S. (2017). Workplace happiness, transformational leadership and affective commitment. Advanced Science Letters, 23(4), 2872-2875. https://doi.org/10.1166/asl.2017.7588

Ali, F., Karamat, M., Noreen, H., Khurram, M., Chuadary, A., Nadeem, M., ..., Farman, S. (2011). The effect of job stress and job performance on employee's commitment. European Journal of Scientific Research, 60(2), 285-294.

Alkhateri, A. S., Abuelhassan, A. E., Khalifa, G. S., Nusari, M., \& Ameen, A. (2018). The Impact of perceived supervisor support on employees turnover intention: The Mediating role of job satisfaction and affective organizational commitment. International Business Management, 12(7), 477-492.

Amin, W., Akram, U., Shahzad, F., \& Amir, M. (2018). Impact of transformation leadership on affective employee's commitment. European Online Journal of Natural and Social Sciences: Proceedings, 7(1 (s)), pp-48.

Akar, H. (2018). The Relationships between Quality of Work Life, School Alienation, Burnout, Affective Commitment and Organizational Citizenship: A Study on Teachers. European Journal of Educational Research, 7(2), 169-180. https://doi.org/10.12973/eu-jer.7.2.169

Baysak, B., \& Yener, M.I. (2015). The Relationship Between Perceived Leadership Style and Perceived Stress on Hospital Employees. Social and Behavioral Sciences., 207, 79-89. https://doi.org/10.1016/j.sbspro.2015.10.159

Boamah, S. A., Laschinger, H. K. S., Wong, C., \& Clarke, S. (2018). Effect of transformational leadership on job satisfaction and patient safety outcomes. Nursing outlook, 66(2), 180-189. https://doi.org/10.1016/j.outlook.2017.10.004

Boxall, P., \& Purcell, J. (2003). Strategy and Human Resource Management. Palgrave Macmillan, Basingstoke.

Brury, M. (2016). Pengaruh Kepemimpinan, Budaya Organisasi, Motivasi Kerja Dan Kepuasan Kerja Terhadap Kinerja Pegawai (Pada Kantor SAR Sorong). Jurnal Riset Bisnis dan Manajemen, Vol. 4 No. 1, 1-16. Retrived from e-journal UNSTRAT (Universitas Sam Ratulangi). https://doi.org/10.26905/jbm.v4i1.1708

Charbonneau, D., \& Wood, V. M. (2018). Antecedents and outcomes of unit cohesion and affective commitment to the Army. Military Psychology, 30(1), 43-53. https://doi.org/10.1080/08995605.2017.1420974

Choi, S. L., Goh, C. F., Adam, M. B. H., \& Tan, O. K. (2016). Transformational leadership, empowerment, and job satisfaction: the mediating role of employee empowerment. Human resources for health, 14(1), 73. https://doi.org/10.1186/s12960-016-0171-2

Dlamini, N. N. N., Garg, A. K., Muchie, M. (2017). The impact of transformational 
leadership style on organisational commitment in the hospitality industry. African Journal of Hospitality, 6(3), 1-21.

DINC, M. S., \& Plakalovic, V. (2016). Impact of caring climate, job satisfaction, and affective commitment on employees' performance in the banking sector of Bosnia and Herzegovina. Eurasian Journal of Business and Economics, 9(18), 1-16. https://doi.org/10.17015/ejbe.2016.018.01

Fernandez-Lores, S., Gavilan, D., Avello, M., \& Blasco, F. (2016). Affective commitment to the employer brand: Development and validation of a scale. BRQ Business Research Quarterly, 19(1), 40-54. https://doi.org/10.1016/j.brq.2015.06.001

Giovanita, D., \& Mangundjaya, W. L. (2017). Transformational Leadership vs Change Self-Efficacy and Its Impact on Affective Commitment to Change. Journal of Management and Marketing Review, 2(4), 13-18.

Gupta, V., Agarwal, U. A., \& Khatri, N. (2016). The relationships between perceived organizational support, affective commitment, psychological contract breach, organizational citizenship behaviour and work engagement. Journal of advanced nursing, 72(11), 2806-2817. https://doi.org/10.1111/jan.13043

Harthantyo, Y., \& Rahardjo, M. (2017). Pengaruh Leader-Member Exchange (Lmx) Dan Percieved Organizational Support (Pos) Terhadap Komitmen Afektif (Studi Kasus Pada Karyawan Rumah Sakit Mekar Sari Bekasi). Diponegoro Journal of Management, 6(4), 1030-1042.

Hayes, A. F. (2018). Partial, conditional, and moderated moderated mediation: Quantification, inference, and interpretation. Communication Monographs, 85(1), 4-40. https://doi.org/10.1080/03637751.2017.1352100

Hayes, A. F., Montoya, A. K., \& Rockwood, N. J. (2017). The analysis of mechanisms and their contingencies: PROCESS versus structural equation modeling. Australasian Marketing Journal (AMJ), 25(1), 76-81. https://doi.org/10.1016/j.ausmj.2017.02.001

Işik, A. N. (2020). Ethical leadership and school effectiveness: The mediating roles of affective commitment and job satisfaction. International Journal of Educational Leadership and Management, 8(1), 60-87. https://doi.org/10.17583/ijelm.2020.4114

Islam, T., Ahmed, I., \& Ahmad, U. N. B. U. (2015). The influence of organizational learning culture and perceived organizational support on employees' affective commitment and turnover intention. Nankai Business Review International. https://doi.org/10.1108/NBRI-01-2015-0002

Jung, M. (2016). Influence of head nurses' ethical leadership on job satisfaction among staff nurses: mediating effect of affective commitment. Journal of Korean Academy of Nursing Administration, 22(5), 553-561. https://doi.org/10.11111/jkana.2016.22.5.553

Joo, B. K., \& Shim, J. H. (2010). Psychological empowerment and organizational commitment: the moderating effect of organizational learning culture. Human resource 
development international, 13(4), 425-441. https://doi.org/10.1080/13678868.2010.501963

Khaola, P. (2019). Fostering creativity and innovation though leadership and affective commitment: The moderated mediation analysis. African Journal of Hospitality, Tourism and Leisure, 8, 1-12.

Kiarie, M. A. W., Maru, L. C., Cheruiyot, T. K. (2017). Leader personality traits and employee job satisfaction in the media sector, Kenya. The TQM Journal, 29(1), 133 - 146. https://doi.org/10.1108/TQM-09-2015-0117

Kiboss, J. K., Jemiryott, H. K. S. (2014). Relationship between Principals' Leadership Styles and Secondary School Teachers' Job Satisfaction in Nandi South District, Kenya. Journal of Education and Human Development, 3(2), 493-509.

Luu, D. T., \& Phan, H. V. (2020). The Effects of Transformational Leadership and Job Satisfaction on Commitment to Organisational Change: A Three-Component Model Extension Approach. The South East Asian Journal of Management. https://doi.org/10.21002/seam.v14i1.11585

Malik, W. U., Javed, M., \& Hassan, S. T. (2017). Influence of transformational leadership components on job satisfaction and organizational commitment. Pakistan Journal of Commerce and Social Sciences (PJCSS), 11(1), 147-166.

Manuel, G. P. E. B., \& Rahyuda, A. G. (2015). Pengaruh Kepuasan Kerja, Komitmen Afektif, Komitmen Kalkulatif, dan Komitmen Normatif Terhadap Turnover Intention di Ayodya Resort Bali. E-Jurnal Manajemen Universitas Udayana, 4(8).

McCormick, L., \& Donohue, R. (2016). Antecedents of affective and normative commitment of organisational volunteers. The International Journal of Human Resource Management. https://doi.org/10.1080/09585192.2016.1166388

Meyer, J. P., \& Allen, N. J. (1991). A Three Component Conceptualization of Organizational Commitment. Human Resource Management Review, 1(1), 61-89. https://doi.org/10.1016/1053-4822(91)90011-Z

Mura, L., Ključnikov, A., Tvaronavičienè, M., \& Androniceanu, A. (2017). Development trends in human resource management in small and medium enterprises in the Visegrad Group. Acta Polytechnica Hungarica, 14(7), 105-122. https://doi.org/10.12700/APH.14.7.2017.7.7

Nawab, S., \& Bhatti, K. K. (2011). Influence of employee compensation on organizational commitment and job satisfaction: A case study of educational sector of Pakistan. International Journal of Business and Social Science, 2(8).

Nguni, S., Sleegers, P., \& Denessen, E. (2006). Transformational and transactional leadership effects on teachers' job satisfaction, organizational commitment, and organizational citizenship behavior in primary schools: The Tanzanian case. School Effectiveness and School Improvement, 17, 145-177. https://doi.org/10.1080/09243450600565746 


\section{Mll Macrothink}

International Journal of Human Resource Studies ISSN 2162-3058 2021, Vol. 11, No. 1

Octaviannand, R., Pandjaitan, N. K., \& Kuswanto, S. (2017). Effect of Job Satisfaction and Motivation towards Employee's Performance in XYZ Shipping Company. Journal of education and practice, 8(8), 72-79.

Park, S. M., \& Rainey, H. G. (2007). Antecedents, mediators, and consequences of affective, normative, and continuance commitment: Empirical tests of commitment effects in federal agencies. Review of public personnel administration, 27(3), 197-226.

Paik, Y., Parboteeah, K. P., \& Shim, W. (2007). The relationship between perceived compensation, organizational commitment and job satisfaction: the case of Mexican workers in the Korean Maquiladoras. The International Journal of Human Resource Management, 18(10), 1768-1781. https://doi.org/10.1080/09585190701570940

Preacher, K. J., Rucker, D. D., \& Hayes, A. F. (2007). Addressing moderated mediation hypotheses: Theory, methods, and prescriptions. Multivariate behavioral research, 42(1), 185-227. https://doi.org/10.1080/00273170701341316

Podsakoff, P. M., Mackenzie, S. B., \& Bommer, W. H. (1996). Transformational leader behaviors and substitutes for leadership as determinants of employee satisfaction, commitment, trust, and organizational citizenship behaviors. Journal of Management, 22, 259-298. https://doi.org/10.1177/014920639602200204

Qing, M., Asif, M., Hussain, A., \& Jameel, A. (2019). Exploring the impact of ethical leadership on job satisfaction and organizational commitment in public sector organizations: The mediating role of psychological empowerment. Review of Managerial Science, 1-28.

Rahman, R., \& Rashid, A. M. (2018). Job Satisfaction as a Mediator of the Relationship between Transformational Leadership Practice and Commitment to Organizational Change among Community College Instructors. European Journal of Social Sciences, 57(1), 80-96.

Rahmi, B. M. (2014). Pengaruh kepimpinan transformasional terhadap organizational citizenship behavior dan komitmen organizational dengan mediasi kepuasan kerja (studi pada guru tetap Sma Negeri di Kabupaten Lombok Timur). E-Jurnal Manajemen Universitas Udayana, 3(2), 330-341.

Rajnoha, R., \& Lesníková, P. (2016). Strategic performance management system and corporate sustainability concept-specific parametres in Slovak Enterprises. Journal of Competitiveness. https://doi.org/10.7441/joc.2016.03.07

Riduan, Engkos \& Achmad Kuncoro. (2012) Cara Mudah Menggunakan Dan Memaknai Path Analisis (Analisis Jalur), Bandung: Alfabeta.

Ribeiro, N., Yücel, İ., \& Gomes, D. (2018). How transformational leadership predicts employees' affective commitment and performance. International Journal of Productivity and Performance Management. https://doi.org/10.1108/IJPPM-09-2017-0229

Riaz, T., Akram, M. U., \& Ijaz, H. (2011). Impact of transformational leadership style on affective employees' commitment: An empirical study of banking sector in Islamabad (Pakistan). The Journal of Commerce, 3(1), 43. 
Riduwan dan Kuncoro. (2013). Cara Menggunakan dan Memaknai Path Analysis.Bandung: Alfabeta.

Robbins, S. P., \& Judge, T. A. (2017). Organizational Behavior 17th Edition. England Jersey: Pearson Education Inc

Sanders, K., Dorenbosch, L., \& de Reuver, R. (2008). The impact of individual and shared employee perceptions of HRM on affective commitment. Personnel Review. https://doi.org/10.1108/00483480810877589

Sang, L., Xia, D., Ni, G., Cui, Q., Wang, J., \& Wang, W. (2019). Influence mechanism of job satisfaction and positive affect on knowledge sharing among project members. Engineering, Construction and Architectural Management. https://doi.org/10.1108/ECAM-10-2018-0463

Shah, S. H. A., Sultana, A., Gul, A., Sajjad, S., Aziz, S., Basit, A., \& Qadir, A. (2020). Transformational Leadership Influence on Innovation Directly and Indirectly through Affective Commitment in Hotel Industry of Malaysia. International Review of Management and Marketing, 10(6), 22-28. https://doi.org/10.32479/irmm.10761

Shah, N., Michael, F., \& Chalu, H. (2020). The Influence of Electronic Human Resource Management Use and Organizational Success: A global conceptualization. Global Journal of Management and Business Studies, 10(1), 9-28.

Sohail, A., Safdar, R., Saleem, S., Ansar, S., \& Azeem, M. (2014). Effect of Work Motivation and Organizational Commitment on Job Satisfaction: (A Case of Education Industry in Pakistan). Global Journal of Management and Business Research: A Administration and Management, 14(6), 41-46.

Shurbagi, A. M. A. (2014). The relationship between transformational leadership style job satisfaction and the effect of organizational commitment. International Business Research, 7(11), 126. https://doi.org/10.5539/ibr.v7n11p126

Tosun, N., \& Ulusoy, H. (2017). The relationship of organizational commitment, job satisfaction and burnout on physicians and nurses?. Journal of Economics and Management, 28(2), 90-111.

Van der Voet, J., Kuipers, B. S., \& Groeneveld, S. (2016). Implementing change in public organizations: The relationship between leadership and affective commitment to change in a public sector context. Public Management Review, 18(6), 842-865. https://doi.org/10.1080/14719037.2015.1045020

Yates, L. A. (2014). Exploring the Relationship of Ethical Leadership with Job Satisfaction, Organizational Commitment, and Organizational Citizenship Behavior. The Journal of Value-based Leadership, 7(1), 1-15.

Yang, L. C., \& Lim, V. C. S. (2016). Empirical Investigation Into The Path-Goal Leadership Theory in the Central Banking Fraternity: Leadership Style and Job Satisfaction. Working Paper, The South East Asian Central Banks (SEACEN) Research and Training Centre Kuala Lumpur, Malaysia. 


\section{Macrothink}

International Journal of Human Resource Studies

ISSN 2162-3058 2021, Vol. 11, No. 1

Yang, M. L. (2012). Transformational leadership and taiwanese public relations practitioners' job satisfaction and organizational commitment. Social Behavior and Personality, 40(1), 31-46. https://doi.org/10.2224/sbp.2012.40.1.31

Yang, Y. C. (2012). High-involvement human resource practices, affective commitment, and organizational citizenship behaviors. The Service Industries Journal, 32(8), 1209-1227. https://doi.org/10.1080/02642069.2010.545875

Yang, T., Guo, Y., Ma, M., Li, Y., Tian, H., \& Deng, J. (2017). Job stress and presenteeism among Chinese healthcare workers: The mediating effects of affective commitment. International journal of environmental research and public health, 14(9), 978. https://doi.org/10.3390/ijerph14090978

\section{Copyright Disclaimer}

Copyright for this article is retained by the author(s), with first publication rights granted to the journal.

This is an open-access article distributed under the terms and conditions of the Creative Commons Attribution license (http://creativecommons.org/licenses/by/4.0/). 